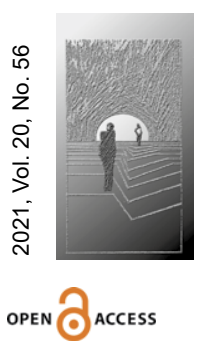

\title{
Tradycja a nowoczesność. Uniwersytet jezuicki a współczesne wyzwania globalizacji
}

\section{STRESZCZENIE}

CEL NAUKOWY: Celem niniejszego opracowania jest przedstawienie najważniejszych elementów koncepcji uniwersytetu jezuickiego w świetle teorii procesów globalizacji.

PROBLEM I METODY BADAWCZE: Główny problem badawczy dotyczy odpowiedzi na pytanie: czy jest możliwe skuteczne połącznie tradycyjnych zasad, na jakich opierał się jezuicki model kształcenia uniwersyteckiego ze współczesnymi potrzebami globalnego rynku „usług” edukacyjnych. W artykule zastosowano metodę analityczno-syntetyczną literatury przedmiotu.

PROCES WYWODU: Artykuł jest skonstruowany w następujący sposób. Na wstępie zarysowano ramy teoretyczne, w jakich analizowane są procesy globalizacji w świetle nauk społecznych. Następnie ukazano najważniejsze cechy koncepcji jezuickiego uniwersytetu, co wreszcie pozwoliło na określenie najważniejszych wyzwań stających przed szkolnictwem wyższym, a w szczególności uniwersytetami jezuickimi.

WYNIKI ANALIZY NAUKOWEJ: Z przedstawionych rozważań wynika, że możliwe jest skuteczne połącznie tradycji jezuickiego modelu kształcenia ze współczesnymi potrzebami rynku edukacyjnego. Co więcej, wydaje się, że jezuicki model uniwersytetu stanowi adekwatną odpowiedź na zmiany spowodowane procesami globalizacji.

WNIOSKI, INNOWACJE, REKOMENDACJE: Wnioski, jakie wynikają z przedstawionych analiz, wskazują przede wszystkim na komplementarność tradycyjnych założeń dotyczących koncepcji uniwersytetu i nowoczesnych modeli edukacyjnych. Tożsamość jezuickiego uniwersytetu wynika w dużym stopniu z przyjęcia całościowej wizji osoby i integralnego modelu formacji. To połącznie tradycji z nowoczesnością wydaje się trafną receptą na rozwój uniwersytetów jezuickich.

$\rightarrow$ SŁOWA KLUCZOWE:

PROCESY GLOBALIZACJI, UNIWERSYTET JEZUICKI, EDUKACJA, SOCJOLOGIA, RATIO STUDIORUM 


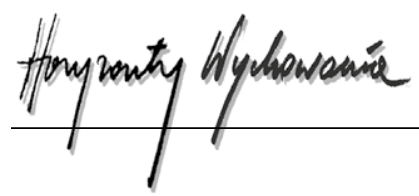

ABSTRACT

Tradition and Modernity. Jesuit University and Contemporary Challenges of Globalization

RESEARCH OBJECTIVE: The aim of this study is to present the most important elements of the Jesuit University concept in the light of globalization processes.

THE RESEARCH PROBLEM AND METHODS: The main research problem concerns the answer to the question: is it possible to effectively combine the traditional principles on which the Jesuit model of university education was based with the contemporary needs of the global market of educational "services"? The article uses the analytical and synthetic method of the literature on the subject.

THE PROCESS OF ARGUMENTATION: The article is structured as follows. In the beginning, the theoretical framework, in which the processes of globalization are analyzed in the light of social sciences, was outlined. Then, the most important features of the concept of the Jesuit university were presented, what finally allowed the researcher to define the most important challenges facing higher education, especially Jesuit universities.

RESEARCH RESULTS: The presented considerations lead to conclusion that it is possible to combine effectively the traditions of the Jesuit model of education with the contemporary needs of the educational market. Moreover, the Jesuit model of the university seems to be an adequate response to the changes caused by the processes of globalization.

CONCLUSIONS, INNOVATIONS, RECOMMENDATIONS: The conclusions that emerge from the presented analyzes indicate, first of all, the complementarity of traditional assumptions concerning the concept of the university and modern educational models. The identity of the Jesuit university comes mostly from adopting a holistic vision of the person and an integral model of formation. The combination of tradition and modernity seems to be an accurate formula for the development of Jesuit universities.

$\rightarrow$ KEYWORDS: GLOBALIZATION PROCESSES, JESUIT UNIVERSITY, EDUCATION, SOCIOLOGY, RATIO STUDIORUM

\section{Wstęp}

W artykule przedstawiono główne zasady, na których Towarzystwo Jezusowe (jezuici) opiera swoje zadania na polu intelektualnym. Ukształtowało się ono już na początku działalności zakonu, a w kolejnych stuleciach przeszło dynamiczny rozwój, tworząc jedną z najważniejszych tradycji edukacyjnych w historii i mając dziś jedną z największych na świecie sieci ośrodków szkolnictwa wyższego.

Ze względu na główny cel artykułu dokonany zostanie przegląd najważniejszych założeń koncepcji uniwersytetu jezuickiego na tle wybranych koncepcji globalizacji w ramach 
nauk społecznych. W celu pełniejszej analizy głównego problemu pracy na wstępie zostaną przedstawione zagadnienia teoretyczne odnoszące się do wybranych koncepcji globalizacji, aby ukazać ramy teoretyczne prowadzonego wywodu. Następnie omówione zostaną główne etapy rozwoju tradycji edukacyjnej jezuitów, a także najważniejsze elementy charakteryzujące ich obecności w świecie uniwersyteckim.

\section{Teoretyczne konteksty opisu globalizacji}

W naukach społecznych często trudno jest prześledzić pochodzenie pojęć. Koncepcje, teorie i idee są często wytworem wspólnych przedsięwzięć. Niezwykle trudno byłoby jednoznacznie określić, kto po raz pierwszy użył terminu „globalizacja”. Według Malcolma Watersa to Roland Robertson był jednym z pierwszych używających tego terminu (Waters, 2000). Bez względu na to, kto go użył jako pierwszy, na początku XXI wieku jest on używany częściej niż jakikolwiek inny (Morawski, 2010).

Globalizacja jako pojęcie w naukach społecznych ma krótką historię, natomiast jako proces społeczny jest znacznie starsza ${ }^{1}$. Wielu pisarzy prześledziło wczesne procesy globalizacji w kontekście rozpowszechniania się religii i kultury, a także interakcji między ludźmi, grupami i społecznościami poprzez handel od czasów starożytnych (Kempny, 2000). Socjologia jest tradycyjnie definiowana jako nauka o społeczeństwie. A ponieważ granice społeczeństwa rozszerzyły się ze społeczności lokalnej poprzez państwa do społeczeństwa globalnego, socjologia stała się nauką o społeczeństwie globalnym. To dobra ilustracja tego, jak idee, wiedza i same nauki (społeczne) rozwijają się wraz ze zmianami i ekspansją geograficzną.

Socjologię często określa się jako naukę zajmująca się życiem społecznym. W rzeczywistości jednak wszystkie nauki społeczne zajmują się życiem społecznym lub jego różnymi aspektami. Trudno jest skonceptualizować „społeczne” jako kategorię. Na potrzeby analizowanego tematu można przyjąć, upraszczając znacznie, że w socjologii istnieją dwa znaczenia tego, co społeczne. Po pierwsze jest używane w znaczeniu, które stosuje Immanuel Maurice Wallerstein, obejmując nim technologię, ekonomię, politykę i kulturę (Wallerstein, 1974). Socjologia wówczas jest skupiona nad rozumieniem tych szerokich procesów, a zwłaszcza ich wzajemnych powiązań (Wallerstein, 2004). Po drugie istnieje także wąskie znaczenie tego, co społeczne, które często utożsamiane jest z abstrakcyjnym systemem relacji społecznych (Krzysztofek, 2001-2002). Za Talcottem Parsonsem, a przed nim Emilem Durkheimem, niektórzy socjolodzy usiłowali określać

${ }^{1}$ W Keywords: A Vocabulary of Culture and Society Raymonda Williamsa (1976) nie ma wpisu o globalizacji, natomiast Słownik socjologiczny HarperCollins (1991) ma wpis o „globalizacji produkcji”, ale nie ma wpisu o globalizacji jako takiej. Oxford Concise Dictionary of Sociology (1994) zawiera wpis o globalizacji wraz z teorią globalizacji. Termin „globalizacja” został prawdopodobnie po raz pierwszy użyty jako tytuł książki Globalization, Knowledge and Society pod redakcją Albrowa i Kinga (1990), która została opublikowana na podstawie esejów zamieszczonych w różnych numerach czasopisma International Sociological Association (1986-1990). 


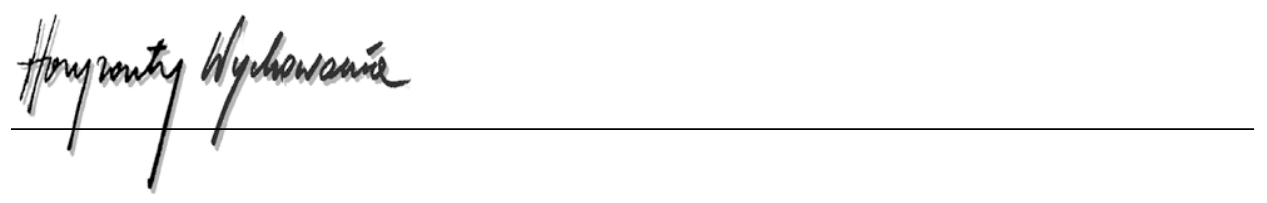

socjologię jako naukowe badanie tego, co społeczne, co skutkuje wąskim zdefiniowaniem dziedziny badań, aby można było wytwarzać i akumulować specjalistyczną wiedzę (Kempny i Woroniecka, 2003).

Jednak wielu socjologów nie przyjmuje wąskiej konceptualizacji tego, co społeczne, szuka szerokiego spojrzenia na społeczeństwo i zakres socjologii. Wielu z nich twierdzi, że wcześniejsze podziały były niepotrzebne, nieproduktywne i nadmiernie abstrakcyjne, dlatego że wszystkie tak zwane podsystemy oddziałują na siebie (Bauman, 2000). Powstanie i dynamiczny rozwój makrosocjologii jest wyraźną odpowiedzią na próbę przezwyciężenia wąskiego poglądu na przedmiot badań socjologii (Bartelson, 2000).

Globalizacja, choć dla wielu ludzi oznacza wiele rzeczy, jest jednym z głównych procesów naszych czasów, jako dziedzina socjologii jest spadkobierczynią zainteresowań i rozwoju makrosocjologicznego (Beck, 2004). Analiza naukowa globalizacji dotyczy badania szerokich procesów wzajemnych relacji technologicznych, ekonomicznych, a także politycznych i kulturowych (Carnoy, 2002). Niezależnie od tego, czy bada się relacje gospodarcze, kulturowe czy medialne, należy odnieść je do szerszego ujęcia instytucji społecznych (Castells, 2007). Socjologia skupia na przepływach i procesach w społeczeństwie, zarówno na poziomie lokalnym, krajowym, jak i globalnym (Anioł, 2002). Badania globalizacji dostarczają cennej wiedzy na temat procesów transformacji w różnych obszarach społecznych, w tym także tych dotyczących szkolnictwa na poziomie akademickim (Castells, 2008). W tym kontekście próba zdefiniowania i analizy wybranych elementów koncepcji uniwersytetów jezuickich może stanowić cenny wkład w debatę nad wyzwaniami, jakie stoją przed szkolnictwem wyższym w dobie globalizacji.

\section{Uniwersytecka misja Towarzystwa Jezusowego}

Towarzystwo Jezusowe narodziło się w środowisku uniwersyteckim, ale nie w celu zakładania kolegiów i uniwersytetów. Miało to miejsce na Uniwersytecie Paryskim, gdzie Ignacy Loyola spotkał swoich pierwszych towarzyszy i to właśnie w tym uniwersyteckim środowisku zrodził się pomysł rozpoczęcia wspólnego dzieła, które później zmaterializowało się w powstaniu zakonu. Pierwsi towarzysze Ignacego znali doskonale życie uniwersyteckie, bo wszyscy byli absolwentami Uniwersytetu Paryskiego, nie zakładali jednak zakonu, który miał służyć wyłącznie edukacji (O’Malley, 1999). Był to zakon o bardzo szerokich i elastycznych założeniach, który miał służyć z „pożytkiem dla dusz”, dlatego też ta misyjna koncepcja poświęcenia zakonu zinstytucjonalizowanej edukacji nie wydawała się początkowo istotna

Ignacy mając jednak podwójne doświadczenie, z jednej strony korzyści płynących z gruntowanego wykształcenia uniwersyteckiego, z drugiej strony widząc katastrofalne efekty braku wykształcenia zarówno wśród duchownych, jak i świeckich, zmodyfikował cele stawiane rozwijającemu się zakonowi. W miarę rozwoju zakonu działalność jezuitów w kolegiach i na uniwersytetach utorowała sobie drogę i stała się niekwestionowanym aksjomatem dla samego Ignacego i jego towarzyszy. Kiedy Ignacy Loyola zmarł 
w 1556 roku, szesnaście lat po założeniu Towarzystwa Jezusowego, w całej Europie uruchomiono już 33 kolegia, a kolejnych sześć zostało zatwierdzonych (Echaniz, 2014).

Od samego początku jezuici otwierali nowe ścieżki edukacyjne. O ile poprzednie zakony poświęcały się przede wszystkim nauczaniu teologii i filozofii, to jezuici promowali nauczanie humanistyczne, aby dać studentom gruntowniejsze i bardziej wszechstronne wykształcenie. Na podstawie tego przekonania zakon projektował system pedagogiczny, który syntetyzował wiedzę o starożytności z nowymi nurtami epoki. Jednym z pierwszych dokumentów pedagogicznych Towarzystwa Jezusowego, który całościowo definiował proces edukacji prowadzonej przez zakon, było Ratio studiorum z 1569 roku, które zawiera deklarację celu (misji) wychowania jezuickiego ${ }^{2}$. Był to dokument, który przez kilka stuleci inspirował i kierował działalnością wychowawczą Towarzystwa Jezusowego. Centralne miejsce zajmowała w nim wizja osoby, która ma „służyć”, oraz wizja świata przekazywana w celu jej doskonalenia. Było to w swoich założeniach bliskie ideałom humanizmu renesansowego, nacechowanego dbałością o rozwój własnych umiejętności, co dziś można by nazywać edukacją spersonalizowaną. Jak wskazuje wielu badaczy, dzięki takim założeniom szkoły jezuickie miały jeden z najlepszych systemów edukacyjnych w Europie przez ponad dwieście lat i ciągle stanowią inspirującą odpowiedź na szybko zachodzące zmiany w życiu społecznym.

Obecnie praca na polu intelektualnym zajmuje dominujące miejsce wśród różnych rodzajów działalności jezuitów. Prowadzą oni działalność na wszystkich poziomach edukacji: uniwersytety, kolegia, ośrodki szkolenia zawodowego i sieci edukacyjne. Prawie 3 miliony studentów korzysta z globalnej sieci edukacyjnej w ponad 4000 ośrodków rozsianych po całym świecie. Obecnie zakon ma około 200 uniwersytetów i ośrodków szkolnictwa wyższego rozmieszczonych na pięciu kontynentach (La Bella, 2020).

Towarzystwo Jezusowe posiada Sekretariat Szkolnictwa Wyższego, którego praca koncentruje się na promowaniu tożsamości jezuickiej w uniwersytetach na całym świecie. Ponadto wspomaga wymianę między uniwersytetami jezuickimi, aby podejmować globalne kwestie społeczne oraz prowadzić kompleksową bazę danych o jezuickim szkolnictwie wyższym. Konkretnym przejawem działalności sekretariatu we współczesnych uwarunkowaniach zglobalizowanego rynku usług jest też zintegrowanie działalności uniwersytetów z innymi instytucjami w jezuickiej sieci placówek edukacyjnych i wychowawczych (Arrupe, 1981).

\footnotetext{
${ }^{2}$ Ratio studiorum to zbiór zasad funkcjonowania i administrowania instytucjami oświaty prowadzonymi przez zakon. W 1551 roku Ignacy Loyola polecił o. Nadalowi spisać porządek szkoły obowiązujący w Mesynie. Ostatecznie projekt przygotował o. Hannibal du Coudret. Collegium Romanum zostało mater omnium scholarum zakładanych przez jezuitów. W 1565 roku przygotowano projekt Ratio studiorum (autorstwa Jakuba Ledesmy i innych profesorów kolegium rzymskiego), który nie został jednak przyjęty. Zaczęto prace nad nową wersją dokumentu, który ogłoszono oficjalnie w 1569 roku. Ratio studiorum ogłoszone przez generała zakonu Franciszka Borgiasza było pierwszym dokumentem organizującym funkcjonowanie szkół na poziomie całego Towarzystwa Jezusowego.
} 


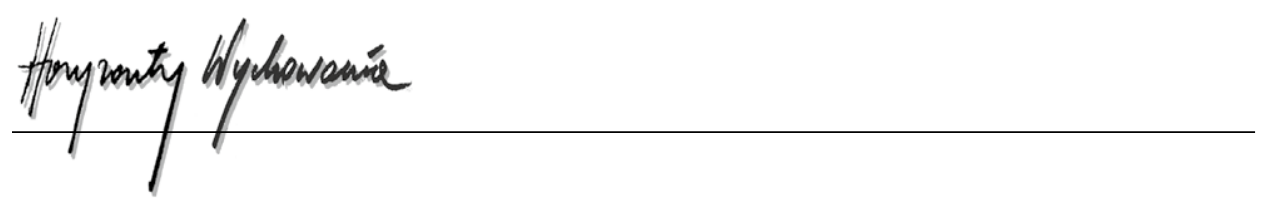

\section{Wyzwania globalnego rynku edukacyjnego}

Obecnie analizowane będą główne wyzwania określone w misji Towarzystwa Jezusowego, które są wspólne dla jezuickich uniwersytetów. Parafrazując słowa Przełożonego Generalnego zakonu jezuitów Adolfo Nicolasa wypowiedziane w 2010 roku, należy stwierdzić, że przed zakonem i przed jezuickimi uniwersytetami stoją te same wyzwania, z którymi mierzy się współczesny świat. Wśród nich kluczowe jest pytanie o sens życia i powiązane z tym kwestie związane z cierpieniem i śmiercią. Te ogólne postulaty są podejmowane w różny sposób w zależności od kontekstu społecznego i uwarunkowań kulturowych. Tym jednak, co jest wspólne dla różnych form działalności uniwersytetów jezuickich, są priorytety określone w następujący sposób: po pierwsze służyć wierze i promować sprawiedliwość, po drugie edukować, by lepiej służyć innym, po trzecie budować współpracę, aby zwiększać uniwersalność działań. W tym kontekście istotne jest podkreślenie, że nie ma żadnej sprzeczności pomiędzy celami, jakie stawia sobie uniwersytet w wymiarze swojej instytucjonalnej działalności a tymi, jakie są na niego „nakładane" w ramach misji, którą ma pełnić jezuicka uczelnia (Nicolas, 2011).

Uszczegółowienie misji uniwersytetu poprzez określenie jej realizacji w ramach idei szerzenia „wiary i sprawiedliwości” było istotnym etapem zdefiniowania miejsca jezuickiej uczelni w zglobalizowanym świecie społecznych interakcji. Ta orientacja była wskazaniem nie tylko dla tych, którzy już pracowali z ubogimi i zepchniętymi na margines społeczeństwa, ale stała się osią integrującą wszystkie elementy misji zakonu, a tym samym także jezuickich uniwersytetów (Puls, 2013).

Aby kreowane procesy mogły być skutecznie realizowane, muszą być wspierane przez odpowiednią koncepcję edukacji, która opiera się na całościowej wizji człowieka i jego integralnej formacji. Dlatego tak istotne jest, aby uniwersytet jezuicki wyróżniał się także w kwestii formacji ludzkiej, duchowej i moralnej. Realizując te ambitne cele, uniwersytet jezuicki nie musi i nie może rezygnować z wysokiego poziomu przygotowania profesjonalnego związanego z przeszkoleniem zawodowym przyszłych absolwentów. Innymi słowy można stwierdzić, że jakość służby na rzecz „wiary i sprawiedliwości” będzie w dużej mierze zależeć od akademickiego rygoru i poziomu badań naukowych. Wszystko to nabiera szczególnego znaczenia w globalizującym się świecie, który stawia nowe wyzwania dla wiedzy i opartej na niej praktyce, co skłania do przywołania charakterystycznego dla jezuickiego charyzmatu kryterium rozeznania w zmieniających się okolicznościach społecznych. W zglobalizowanym świecie, pod silnym wpływem technologii informacyjnych i komunikacyjnych, Towarzystwo Jezusowe stawia nowe wyzwania dla misji jezuickich uniwersytetów, którą staje się uniwersalność ich działalności. W tym kontekście uniwersytety powinny w duchu rozeznania i kreatywności kontynuować spuściznę jezuickiej posługi intelektualnej i budować mosty między Ewangelią a kulturą oraz wiarą i rozumem.

Jednym z wyznaczników uniwersalności prowadzonych działań powinien być zakres podejmowanych wyzwań i realizowanej odpowiedzialności. Odpowiedzialność ta powinna także przejawiać się w szerokiej współpracy z przedstawicielami różnych środowisk 
społecznych i religijnych. Uwzględniając wielość uwarunkowań zmieniających się kontekstów kulturowych, uniwersalność w zglobalizowanym świecie wymaga wspólnej refleksji prowadzonej przez różne instytucje należące do jezuickiego systemu edukacji. W tym kontekście szczególnie uniwersytety jezuickie są wezwane do pracy nad utworzeniem międzynarodowej sieci, która będzie koordynowała refleksje nad kluczowymi kwestiami dotyczącymi wiary, sprawiedliwości i ekologii będącymi wyzwaniami wykraczającymi poza kraje i kontynenty (Lowney, 2011).

Termin „globalizacja” wszedł do powszechnego użycia dopiero pod koniec XX wieku, gdy dyscypliny akademickie i komentatorzy medialni zmagali się z przyspieszającymi transnarodowymi przepływami ludzi, idei, towarów i kapitału, możliwymi dzięki trwającym rewolucjom w technologiach informacyjnych, komunikacyjnych i transportowych (Magala, 1985). Tworzące się w ten sposób coraz bardziej złożone sieci powiązań doprowadziły w szybkim tempie do powstania globalnego społeczeństwa wymiany (Held, 2002). W tym kontekście warto dokonać rozróżnienia na to, co można nazwać wymiarem „subiektywnym” i „obiektywnym” globalizacji. Obiektywne procesy globalizacji, w których pośredniczą zmiany w technologii komunikacji i transportu, obejmują przemieszczanie się ludzi, idei, towarów i kapitału na większe przestrzenie. Subiektywny wymiar globalizacji odnosi się do wzrostu globalnej świadomości, to znaczy do rosnącego poziomu refleksyjnej świadomości ludzkości jako gatunku dzielącego tę samą historię i tę samą planetę (Bairoch, 2000).

Od swojego powstania w połowie XVI wieku Towarzystwo Jezusowe było ściśle związane z tak rozumianymi procesami globalizacji. We wczesnej epoce nowożytnej po iberyjskiej ekspansji kolonialnej jezuici stali się „pionierami globalizacji”, zakładając misje i instytucje edukacyjne na całym świecie. Wypracowali szczególny „sposób postępowania", który często charakteryzował się elastycznym dostosowywaniem się do lokalnych warunków, łączącym wiarę w Ewangelię z afirmacją pozytywnych cech napotykanych kultur. W następstwie dwóch wojen światowych, dekolonizacji i Soboru Watykańskiego II (1962-65) Towarzystwo Jezusowe odnowiło swoje globalne zaangażowanie, kładąc nacisk na promocję sprawiedliwości i powszechnego dobra wspólnego jako część służby wierze. Pół wieku później, w epoce przyspieszającej globalizacji, jezuici podążając za przykładem papieża Franciszka w odkrywaniu nowych sposobów towarzyszenia ubogim i wykluczonym, promują taki system edukacji, który wspiera, zgodnie ze słowami papieża, odejścia od tego, co nazywa on „globalizacją obojętności” na rzecz "globalizacji braterstwa" (La Bella, 2020).

Uzasadnione wydaje się założenie, że współczesna faza globalizacji ma swoje korzenie w powojennych dekadach wraz z powstaniem kulturowej i politycznej dominacji Stanów Zjednoczonych Ameryki, budową systemu Narodów Zjednoczonych i rozpadem pozostałych imperiów Europy (Chirot, 1988). Pod przywództwem USA powstał światowy system praw człowieka, wyrażony w Powszechnej deklaracji praw człowieka Zgromadzenia Ogólnego ONZ. Idea uniwersalnych praw człowieka pogłębiła subiektywny wymiar globalizacji i świadomość przynależności do wspólnego „człowieczeństwa” (Gabiś, 2003). Ten wymiar dopełniały obiektywne siły technologiczne, które zbliżyły różne 


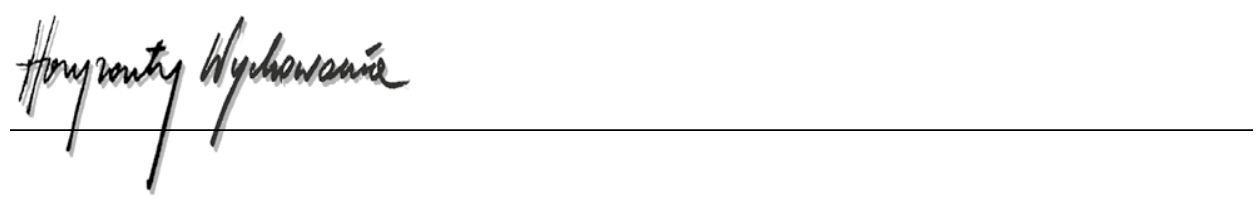

części świata „do siebie”, czego symbolicznym opisaniem było użyte przez Marshalla Mc Luhana określenie „globalna wioska” (2019).

Pełniejsze otwarcie na społeczno-kulturowe przemiany nastąpiło w Kościele katolickim podczas Soboru Watykańskiego II. Wiązało się to z trzema powiązanymi zmianami: przyjęciem praw człowieka i wolności religijnej, otwarciem na dialog międzyreligijny oraz coraz bardziej globalną perspektywą dla katolickiej myśli i praktyki społecznej. Nowe priorytety miały głębokie implikacje dla dwóch głównych aspektów działalności jezuickiej - misji i edukacji.

W pięćdziesiąt lat od otwarcia Kościoła na współczesny świat na Soborze Watykańskim II większość jezuickich instytucji szkolnictwa wyższego aspiruje nie tylko do dążenia do profesjonalizacji i posługi wiary, ale także promowania sprawiedliwości na świecie. Ta nowa orientacja jezuickiego szkolnictwa wyższego na globalne dobro wspólne stworzyła możliwości głębszej międzynarodowej współpracy między jezuickimi uniwersytetami. Globalizacja nie tylko wpłynęła na misję i tożsamość Towarzystwa Jezusowego, w tym także uniwersytetów, ale umożliwiła również nowe formy ponadnarodowej interakcji w ramach nowych zasad globalnego rynku wymiany.

\section{Wnioski}

Doświadczenia jezuickiego systemu szkolnictwa wyższego z poprzednich dekad i stuleci jest przydatne dla tych instytucji w obecnej fazie globalizacji. Towarzystwo Jezusowe bada, podobnie jak w okresie nowożytnym, możliwości głębszego spotkania kulturowego w epoce pluralizmu. Jezuicka sieć edukacyjna ze swoją globalną i międzykulturową orientacją ilustruje możliwości skutecznego dialogu i współpracy dla globalnego dobra wspólnego. Ukazuje także, jak organizacje religijne mogą współpracować ze świeckimi partnerami, by służyć zmarginalizowanym i przeciwdziałać wykluczeniu.

Jezuicka sieć edukacyjna, mimo że jest mniejsza, mniej scentralizowana i mniej połączona z elitami politycznymi i gospodarczymi niż jeszcze sto lat temu, to jednak nadal pozostaje wpływowa w wielu obszarach społecznych. Jak zauważył papież Franciszek, działanie na peryferiach, a nie w centrach globalizacji może być pożyteczne. Dziś, bardziej niż kiedykolwiek, misja jezuitów - i Kościoła - koncentruje się bowiem mniej na nauczaniu i nawróceniu, a bardziej na słuchaniu i towarzyszeniu ludziom wykluczonym, tym, którzy najbardziej odczuwają skutki współczesnych procesów globalizacji.

Analizując współczesne teorie globalizacji przez pryzmat historii jezuitów i rozwoju ich uniwersytetów, można wyciągnąć także konkretne i praktyczne wnioski. Doświadczenie jezuitów potwierdza niewątpliwie słuszność tych teorii globalizacji, które podkreślają pozorną sprzeczność w dynamice procesów homogenizacji i heterogenizacji, a także akcentują silne powiązanie tego, co globalne i lokalne. Historia jezuitów podważa proste i jednoznaczne narracje oraz jednowymiarowe teorie globalizacji.

Otwartym wciąż pytaniem w tym kontekście pozostaje, na ile uniwersytety jezuickie mogą współcześnie w sposób kreatywny i dynamiczny kontynuować spuściznę 
edukacyjną zakonu oraz budować nowe płaszczyzny dialogu w zmieniających się kontekstach społecznych. Prezentowane w tym artykule analizy stanowią próbę odpowiedzi na to pytanie, a także mogą stanowić inspiracje do dalszych poszukiwań.

\section{BIBLIOGRAFIA}

Albrow, M. i King, E. (red.). (1990). Globalization, knowledge and society. Sage Publications. Anioł, W. (2002). Paradoksy globalizacji. Oficyna Wydawnicza ASPRA-JR.

Arrupe, P. (1981). Jesuit mission in the university education. W: J. Aixala (red.), Jesuit apostolates today (s. 80-95). Anand Press.

Bairoch, P. (2000). The constituent economic principles of globalization in historical perspective. Myths and realities (M. Kendall i S. Kendall, tłum.), International Sociology, 15(2), 197-214.

Bartelson, J. (2000). Three concepts of globalization. International Sociology, 15(2), 180-196.

Bauman, Z. (2000). Globalizacja. I co z tego dla ludzi wynika (E. Klekot, tłum.). Państwowy Instytut Wydawniczy.

Beck, U. (2004). Globalizacja kosmopolityczna. Twórcze samounicestwienie się porządku światowego (A. Milewska, tłum.). Przegląd Polityczny, 64, 132-135.

Carnoy, M. (2002). Utrwalanie nowej gospodarki. Praca, rodzina i społeczność w wieku informacji (A. Gwiazda, tłum.). Towarzystwo Naukowe Organizacji i Kierownictwa „Dom Organizatora”.

Castells, M. (2007). Społeczeństwo sieci (M. Marody i in., tłum.). Wydawnictwo Naukowe PWN.

Castells, M. (2008). Siła tożsamości (S. Szymański, tłum.). Wydawnictwo Naukowe PWN.

Chirot, D. (1988). Rozkwit świata zachodu (J. Stawiński, tłum.). W: A. Czarnota i A. Zybertowicz (red.), Interpretacje wielkiej transformacji. Geneza kapitalizmu jako geneza współczesności (s. 23-59). Rada Naczelna Zrzeszenia Studentów Polskich.

Echaniz, I. (2014). Męka i chwała. Żywa historia jezuitów (B. Steczek, tłum.). Wydawnictwo WAM.

Gabiś, T. (2003). Imperium Mundi - polityczna forma globalizacji. Obywatel, 3, 54-60.

Gordon M. (red.). (1994). The concise Oxford dictionary of sociology. Oxford University Press.

Held, D. (2002). Czy można regulować globalizację? (M. Szuster, tłum.). Krytyka Polityczna, 2, 231-245.

Kempny, M. (2000). Czy globalizacja kulturowa współdecyduje o dynamice społeczeństw postkomunistycznych? Kultura i Społeczeństwo, 1, 5-26.

Kempny, M. i Woroniecka, G. (red.). (2003). Wymiary globalizacji kulturowej. Wyzwania badawcze. Wydawnictwo Wyższej Szkoły Informatyki i Ekonomii Towarzystwa Wiedzy Powszechnej.

Krzysztofek, K. (2001-2002). Globalizacja - interpretacje i spory. Transformacje, nr 1/4, 252-265.

La Bella, G. (2020). Jezuici. Od Vaticanum Il do papieża Franciszka. Epoka burzliwych procesówwyzwania dla Kościoła (A. Koprowski, tłum.). Kontrast.

Lowney, C. (2011). Heroiczne przywództwo. Tajemnica sukcesu firmy istniejącej ponad 450 lat (Ł. Malczak, tłum.), Wydawnictwo WAM.

Magala, S. (1985). Między rynkiem a imperium (koncepcja „systemów globalnych” I. Wallersteina). Przegląd Literatury Metodologicznej, 2, 33-43.

McLuhan, M. (2019). Galaktyka Gutenberga. Tworzenie człowieka druku (A. Wojtasik, tłum.). Narodowe Centrum Kultury.

Morawski, W. (2010). Konfiguracje globalne. Struktury, agencje instytucje. Wydawnictwo Naukowe PWN.

Nicolas, A. (2011). Challenges to Jesuit higher education today. Conversations on Jesuit Higher

Education, 40, 5. https://epublications.marquette.edu/conversations/vol40/iss1/5

O’Malley, J.W. (1999). Pierwsi jezuici (P. Samerek i in., tłum.). Wydawnictwo WAM. 


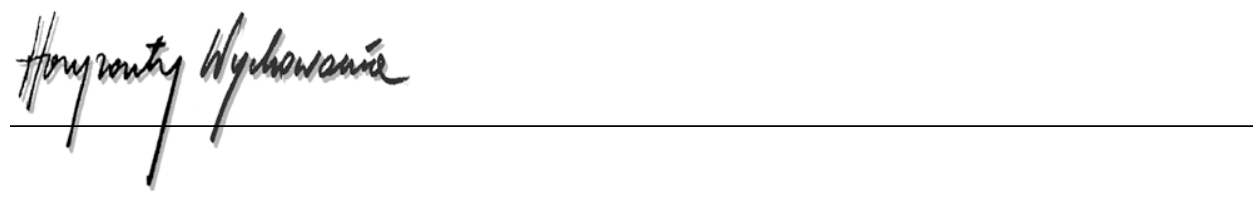

Puls, Ch.W. (2013). Saga and socialization in Jesuit institutions. Jesuit Higher Education: A Journal, 2(2), 6-19.

Wallerstein, I. (1974). The modern world-system: Capitalist agriculture and the origins of the European world economy in the sixteenth century. Academic Press.

Wallerstein, I. (2004). Koniec świata jaki znamy (M. Bilewicz, A.W. Jelonek i K. Tyszka, tłum.). Wydawnictwo Naukowe Scholar.

Waters, M. (2000). Globalization. Routledge.

Williams, R. (1976). Keywords: A vocabulary of culture and society. Oxford University Press.

\section{Copyright and License}

This article is published under the terms of the Creative Commons Attribution - NoDerivs (CC BY- ND 4.0) License http://creativecommons.org/licenses/by-nd/4.0/ 